\title{
Paideusis
}

\section{Teacher Autonomy: A Professional Hazard?}

Howard Woodhouse

Volume 4, Number 1, 1990

URI: https://id.erudit.org/iderudit/1073393ar

DOI: https://doi.org/10.7202/1073393ar

See table of contents

Publisher(s)

Canadian Philosophy of Education Society

ISSN

0838-4517 (print)

1916-0348 (digital)

Explore this journal

Cite this article

Woodhouse, H. (1990). Teacher Autonomy: A Professional Hazard? Paideusis, 4(1), 32-38. https://doi.org/10.7202/1073393ar

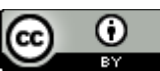

This document is protected by copyright law. Use of the services of Erudit (including reproduction) is subject to its terms and conditions, which can be viewed online.

https://apropos.erudit.org/en/users/policy-on-use/
This article is disseminated and preserved by Érudit.

Érudit is a non-profit inter-university consortium of the Université de Montréal, Université Laval, and the Université du Québec à Montréal. Its mission is to promote and disseminate research.

https://www.erudit.org/en/ 


\title{
Teacher Autonomy: A Professional Hazard?
}

\author{
Howard Woodhouse \\ University of Saskatchewan
}

\section{Is Teaching a Profession?}

A recent report, entitled Teacher Education in Ontario: Current Practice and Options for the Future, argues for the professionalization of teaching by removing experienced teachers from the classroom for much of the working day. 1 The rationale for this move is to enable such teachers to be closely involved with curriculum development, school administration, and the enforcement of professional standards in teaching practice. Meanwhile, classrooms would be tended by junior teachers, known variously as "inducted" or "apprentice" teachers (76).

While the idea that teachers engage in a diversity of tasks suited to their own capacities may well appear attractive, ${ }^{2}$ it is the context in which the report urges these recommendations that makes them anti-educational. Teacher Education in Ontario argues for a structured hierarchy in which the professional expertise of teachers is enforced by the most senior or "mentor" teachers, many of whom would no longer set foot inside a classroom to teach, but who would possess most of the powers of their superintendent predecessors. This is presented as though it would be liberating for teachers, presumably because mentor teachers would perform the tasks previously carried out by officials from school boards and Ministries of Education (76-7).

In this paper, I shall argue that if the professionalism advocated in Teacher Education in Ontario were implemented it would do irreparable harm to education. In order to support this conclusion, I shall consider two main points from the report. The first will be a critical examination of the report's conception of professionalism, showing it to be inconsistent and likely to hinder the teaching process. The second will be an examination of the report's proposal that teachers become "reflective, critical and inquiring" (50), showing that it fails to define what is meant by this. I shall suggest that the notion of teachers as critical thinkers could form the basis of a revitalized conception of teaching and learning. In order to do so, however, teachers and students alike need to enjoy academic freedom, not be burdened with the mantle of professionalism.

\section{The Dangers of Professionalism in Teaching}

Professionalism, according to Teacher Education in Ontario, will enhance the quality of education in schools, since teachers will then be

\footnotetext{
Viewed as a profession consisting of individuals who make judgments about teaching and learning, who are granted the authority to carry forward the consequences of their judgments, and who are responsible for their own continuing education. (44)
}

The main objective of this process for teachers is the enjoyment of "the autonomy of professional work" (42), otherwise referred to as "creative, professionally autonomous work" (53), but never fully defined. Such work is supposedly made possible by a concept of professionalism that "has both per- 
sonal and collective dimensions" (49) and takes into account those personal aspects of teachers' lives that have enabled them to become knowledgeable in particular disciplines, and the various ways in which they share knowledge with colleagues (48-9). This claim to encompass the personal and the collective is rapidly undermined once the report goes on to define professionalism more precisely.

The report proposes "collective professionalism" (51) as the aim of all teachers. What the report means by this is as follows:

Unacceptable is the extreme of teacher as individual professional. It is not a matter of allowing individual teachers "to do their own thing" under the guise of professionalism (51).

In this cavalier manner, the report dispenses with the personal freedom of teachers to pursue knowledge in conjunction with students, with whom they also share the freedom to inquire about the structure and content of their disciplines. In its place, accountability becomes the primary responsibility of teachers considered as collective or "interactive" (51 and 58) professionals (the two terms are used interchangeably). To whom, one may ask, will teachers now be accountable? To other collective professionals, who will determine for the individual teacher what is the appropriate professional behaviour "in identifying, and upgrading, and enforcing standards of practice". (51)

The problem with this idea of a new professional accountability is that it is quite likely to be more tyrannical than the present system. The report's recommendation that a rigidly structured professional guild of teachers be given the responsibility for this onerous task is hardly a means to liberation. First, it will likely be more burdensome on those junior teachers being supervised than present arrangements. Second, what of those senior teachers who regarded such bureaucratic work as less important than their classroom teaching? Would they be required to perform supervisory duties, and if they refused, would they be less likely to secure promotion? Third, the report has in mind a medical model of professionalism, in which there is a strict hierarchy defining the roles of doctors, nurses and nurses' aides (62). This, according to the report, is precisely the kind of classification to be emulated in teaching where, in descending order, the corresponding layers of mentor teacher, apprentice teacher, inducted teacher and practice teacher would characterise the profession (76-7). ${ }^{3}$ One aim of this hierarchy is to place "emphasis on the expertise within the profession" (77) in order to guarantee the appropriate methods of "structured, supervised induction and apprenticeship" (76). A further aim is to ensure a greater salary differential between inducted and mentor teachers than at present (76). Its overall aim, however, is to develop a sense of professionalism as close to that of medicine and law as possible, since

We need to trust our teachers in the same way we trust our lawyers, doctors and architects, no more no less. (50)

The problem is that we no longer trust any of these professionals as we once did. A recent doctor's strike in Ontario in favour of extra billing, for example, was defeated by the provincial government with the full support of the public who perceived the action as a grasping attempt by doctors to get more money. Is this the type of professional that teachers are to become? Why should they try to be like lawyers who enjoy low credibility in the eyes of the public? To cast 
teachers in either of these roles strikes one as a losing strategy whose effect would endanger the credibility of the public school system in the eyes of the public. The report's desire to rigidly structure the teaching profession is a throwback to an earlier age of guilds that held a monopoly over the knowledge that they possessed and exerted secrecy over that knowledge, as well as over strict methods of induction into the patriarchal brotherhood. ${ }^{4}$ That the report should choose this model of professionalism in teaching is especially ironical, given its emphasis on the need for dialogue and shared knowledge among teachers (48-9), as well as the need to move beyond the assumptions of an earlier industrial age about their role and status (48). Once again, the model suggested by the report is wide of the mark because it would be divisive of teachers and would undermine any sense of collegiality.

There is an underlying presupposition at the root of the report's entire strategy that the major professions in this word are medicine, law, and architecture, whose knowledge and organisational structures are well established, and hence worthy of emulation by teaching. This presupposition, which is widely shared, ${ }^{5}$ has recently been challenged, since it is far from clear that either the structures of knowledge in medicine, for example, or the methods of teaching medical knowledge have served the profession well. Rather, they have resulted in the regurgitation of inert ideas, not the integration of dynamic principles by fledgeling practitioners. ${ }^{6}$ Similarly, the rigid organizational structures dividing doctors from nurses from nurses' aides are currently being challenged by nurses in the United States, who regard them as technocratic and incompatible with the caring that they see as fundamental to their relationship with patients. ${ }^{7} \mathrm{~A}$ growing body of evidence shows that the report's presupposition about teaching needing to emulate the "major professions" is quite unfounded.

One further surprise contained in the report's conception of professionalism is that, by adopting it, the school system will supposedly do away with bureaucracy at one and the same time. Because teachers as a group will be professionally involved in enforcing public and professional accountability, the report asserts that bureaucracy will somehow wither away and the schools become non-bureaucratic $(42,44,48-50,53,56,63-4)$. Not surprisingly, this belief is argued for only in oblique fashion (51). Indeed, no evidence is given to support it, other than the innuendo that any alternative will lead to certain chaos. In light of the bureaucratisation that has accompanied the growth of the professions of medicine and law, it is disingenuous of the report to suggest that the professionalization of teaching will somehow be different. The kinds of regulation and standardization of teaching practice that the report itself envisages mentor teachers enforcing on their own colleagues will require a considerable bureaucracy that will strenuously resist any withering away. In any case, teachers will not be solely responsible for the credentializing of their colleagues. It is the state that will continue to legitimise this process, as it does now. To suggest that teachers will somehow become free of any relationship with the bureaucracy of the state flies in the face of the historical precedents set by all the other professions. ${ }^{8}$

At almost every turn, therefore, the report fails to give a satisfactory explanation of collective or interactive professionalism in teaching. None of the extravagant claims made about it turns out to be beneficial to teaching or to education in general. Indeed, they may do both considerable harm. Is there 
anything that can be salvaged from the report's account? Or is the notion of professionalism in teaching to be shelved and replaced by that of academic freedom that would enable the teaching of critical thinking in schools? It is to this question that I shall turn in the following section.

\section{The Critical Teacher and Academic Freedom}

\section{At one point in Teacher Education in Ontario the authors state that}

We need teachers who are reflective, critical and inquiring. We need teachers who are comfortable with problems and for whom genuine discussion and inquiry with students is valued. (50)

This conception of critical and reflective teachers is a most important one. Unfortunately, the report in no way tries to define it in more precise terms. ${ }^{9}$ What constitutes the posing of problems and the process of inquiry and how do they relate to critical reflection? These and other questions go begging in the report. For example, there is no explanation attempted of how critical and reflective teachers will manage to engage in this art within their new role as collective/interactive professionals. Since personal autonomy is largely excluded, how will teachers manage to create that reflective space either in themselves or their students that will enable critical thinking to become a reality? It is hardly surprising that the report attempts no clarification of this point, since without some form of personal autonomy, critical thinking is impossible.

In this section, I shall propose a conception of critical thinking based in the very disciplines of thought that are taught in schools. The study of these disciplines, along with their structures, content and norms of explanation and understanding, give to both teacher and learner the conceptual and normative potential to use and question them. In becoming familiar with the disciplines of thought, it is possible for those engaged in the asking of questions that constitutes inquiry to ask further critical questions that call for change either in the discipline or in reality or both. Only where teachers and students enjoy the academic freedom to express their views without fear of censure, however, will critical thought flourish. This notion of critical thought, allied with academic freedom, takes us far away from the professionalism touted in Teacher Education in Ontario to greener pastures where ideas can be exchanged in an open, reflective and critical manner that is truly educational. Only then will schools be responsible to the needs of teachers and students alike, as they are allowed to pursue critical inquiry within and among the various disciplines of thought.

The conception of knowledge that underpins critical thought is rooted in the asking of questions. Knowledge, indeed, is a process of asking questions in a systematic way. These questions may be posed of reality, of subject matter or both. They become critical when they show this reality or subject matter to be problematical or in need of revision. 10 The process of critical inquiry constitutes the basis of human learning and is crucial to education in the sense that it "enables a more inclusive range of thought, experience or action." 11

The most likely way for schools to embody educational principles enabling inclusive thought and action is to allow teachers and students to enjoy academic freedom. Open discussion at any level is impossible without academic freedom being granted to both of these parties. This fact is partially recognized at universities, at least for those university teachers who have tenure. However, 
schools have no such clauses to protect teachers who advocate views unpopular to those in power. On the one hand, the Canadian Association of University Teachers' Model Clause on Academic Freedom protects the rights of their members to carry out and publish research, engage in teaching and discussion, and criticize the university itself free from institutional censorship. ${ }^{12}$ On the other hand, teachers' federations and associations avidly protect their members' salary demands, but do little to ensure the defence of their intellectual independence in the collective agreements that they obtain.

One reason given for this state of affairs is that schools are not expected to raise controversial matters. Students in schools, so it is said, are too immature to grasp the complexities of social, ethical and political issues. They can only be expected to grasp the rudiments of the school curriculum. Thus, the role of teachers is to develop the basic skills among students who may later refine them if they succeed in going to university. After all, teachers themselves (unlike their university counterparts) do not engage in research or publishing and are not familiar with the most recent findings in areas of controversy.

This authoritarian argument negates the capacities of both students and teachers alike. By decrying the lack of intellectual capacities among the former, it severely curtails the activities of the latter. In suggesting that teachers are incapable of doing research, the argument denies to students access to vibrant ideas at the base as well as the forefront of knowledge. Moreover, it propagates "the pervasive boredom and apathy of the students and the cognitive closure and inertia of teachers" 13 that is to be found in too many schools.

Moreover, to suppose that students can grasp the rudiments of the curriculum or develop basic skills in the various disciplines without the freedom to ask questions of a critical nature is poor pedagogy indeed. Learning does proceed by asking questions and these at some point become critical in their orientation. If schools disallow this process, they stifle learning and become anti-educational. In this context, it is not surprising that the quality of learning declines to the point that too many secondary school graduates are subliterate and subnumerate, as well as excruciatingly bored.

Were Teacher Education in Ontario really concerned that schools be filled with "students who are teachable" (52), it would have done more than simply advocate teacher professionalism. To the extent that this removes the best qualified teachers from the classroom and gives them a variety of bureaucratic tasks (63), including the enforcement of professional standards upon their junior colleagues (51), then such a reform is likely to lower the quality of education in schools. If, however, teachers were afforded greater opportunities to engage with their students in critical inquiry, in the sense of asking questions about both disciplines and reality, and showing either to be in need of revision, then schools would become dynamic places that encourage the open, critical and reflective discussion of ideas. In order for this to happen both teachers and students would need to enjoy the academic freedom that protected them from any kind of censure. ${ }^{14}$ Students would then be both teachable and critical. Teachers would be active and critical inquirers, and schools might actually succeed in causing both teachers and students to grow. This, as the Latin root educare reminds us, is the original meaning of education. 


\section{Notes}

${ }^{1}$ Michael Fullan and F. Michael Connelly, Teacher Education in Ontario: Current Practice and Options for the Future, Toronto, Ontario Ministry of Colleges and Universities, 1987, 61-3. Further references to this report appear in the text. The kind of educational critique that I engage in in this paper is consistent with the suggestions made by Brian Hendley, Dewey, Russell, Whitehead: Philosophers as Educators, (Carbondale and Edwardsville, Southern Illinois University Press, 1986), 109-111, and in his "A Deweyan Reaction to Ed Schools," Paideusis, 4(1), 1990.

${ }^{2} \mathrm{Nel}$ Noddings, Caring: A Feminine Approach to Ethics and Moral Education (Berkeley, University of California Press, 1984), 199-200.

${ }^{3}$ This division is maintained in the report's successor, Final Report of the Teacher Education Review Steering Committee (Toronto, Ministry of Education and Ministry of Colleges and Universities, 1988), 32.

${ }^{4}$ Howard Woodhouse and Innocent Enukoha, "The Hidden Curriculum and Beyond: A Nigerian Case Study," International Journal of Educational Development, 6(2), 1986, 105-6.

"Nathan Glazer, "The Schools of the Minor Professions" Minerva, 12, (July) 1974, 346-64. For a Swedish study that shows that it is teachers with a poorly developed outlook on human beings and society who rely on a professional code, see Anders Tornvall, "Teachers' Basic Philosophies and the Curriculum," The Journal of Moral Education, 14(2), 1985, 75-86.

'David Boud, "Problem-Based Learning in Perspective," in David Boud (ed.), Problem-Based Learning in Education for the Professions (Sydney: Herdsa, 1985), 13; Dwight Boyd, "Issues of Professionalism in Teaching: Moral Dilemmas in Moral Education," a paper presented to the American Educational Studics Association, Toronto, November 2-6, 1988; Howard R. Woodhouse, "Bay Street Is Not the Only Avenue Open to Education," The Globe and Mail, October 17, $1988,7$.

${ }^{7}$ Nel Noddings, "The Impact of Feminism on the Professions," a lecture in the series entitled "Alternative Education: A Forgotten Tradition?", Independent Studies Program, University of Waterloo, October 12, 1988.

8Terry Johnson, "Professionalism: Occupation or Ideology?" in Sinclair Goodlad (ed.), Education for the Professions (Guildford, University of Surrey Press, 1984), 20-1.

${ }^{9}$ Final Report of the Teacher Education Review Steering Committee, 5. Interestingly enough, this is the only passage from the report that is quoted in its successor, which may indicate that there is an awareness of the importance of critical thinking in teaching and learning.

${ }^{10} \mathrm{John}$ McMurtry, "The History of Inquiry and Social Reproduction: Educating for Critical Thought," Interchange, 19(1), 1988, 31.

${ }^{11}$ I bid., 39.

${ }^{12}$ Canadian Association of University Teachers, "Model Clause on Academic Freedom for Collective Agreements and Faculty Handbooks," Handbook of Policy Statements, Guidelines and Model Clauses (1977), 4. I am grateful to a senior official at the Ontario Secondary School Teachers Federation for clarifying some of the issues with regard to academic freedom and teachers.

${ }^{13}$ McMurtry, op. cit., 40. 
${ }^{14} \mathrm{~A}$ precedent for granting academic freedom to students already exists in the German universities of the nineteenth century. See Walter P. Metzger, "Academic Freedom and Scientific Freedom," in Limits of Scientific Inquiry, (New York: Norton, 1978), 95. 